\title{
Floods of the Upper Danube River and Its Tributaries and Their Impact on Urban Economies (c. 1350-1600): The Examples of the Towns of Krems/Stein and Wels (Austria)
}

\section{CHRISTIAN ROHR}

Institute of History and Oeschger Centre for Climate Change Research University of Bern

Länggassstrasse 49, CH-3012 Bern, Switzerland

Email: christian.rohr@hist.unibe.ch

\begin{abstract}
This paper examines the impact of disastrous and 'ordinary' floods on human societies in what is now Austria. The focus is on urban areas and their neighbourhoods. Examining institutional sources such as accounts of the bridge masters, charters, statutes and official petitions, it can be shown that city communities were well acquainted with this permanent risk: in fact, an office was established for the restoration of bridges and the maintenance of water defences and large depots for timber and water pipes ensured that the reconstruction of bridges and the system of water supply could start immediately after the floods had subsided. Carpenters and similar groups gained 10 to 20 per cent of their income from the repair of bridges and other flood damage. The construction of houses in endangered zones was adapted in order to survive the worst case experiences. Thus, we may describe those communities living along the central European rivers as 'cultures of flood management'. This special knowledge vanished, however, from the mid-nineteenth century onwards, when river regulations gave the people a false feeling of security.
\end{abstract}

\section{KEYWORDS}

Austria, Danube River, flood management, flood frequency, bridges, municipal accounts, urban economy, Late Middle Ages, Early Modern Times. 


\section{CHRISTIAN ROHR}

\section{INTRODUCTION}

Historical hydrology has been a very active field of research in the last twenty years. There exist several case studies on floods in late medieval, early modern and modern Austria, mostly focussing on early modern times, and the nineteenth and twentieth centuries. ${ }^{1}$ Floods are also included in general studies of natural hazards in historical Austria. ${ }^{2}$ Publications on Austrian climatic and flood history mostly deal with the period following the beginning of systematic measurement of temperature and water level in the second half of the eighteenth century. ${ }^{3}$ Nevertheless, compared to some neighbouring countries, such as Germany, ${ }^{4}$ Switzerland, ${ }^{5}$ the Czech Republic, ${ }^{6}$ Hungary ${ }^{7}$ or Central and Southern Europe in general, the body of studies is relatively sparse. ${ }^{8}$

The economic aspect of floods in what is now Austria, however, has still not been scrutinised in any detail. This is, indeed, remarkable because many of the old Roman and medieval towns were situated alongside the river, and used it for transport and energy. This raises many questions. How often were those cities hit by floods and what was the average damage? How did the afflicted people cope with frequent floods? What did the urban authorities or the landlords undertake to diminish the damage? Was there a social network for the people who lost their property or their basis to survive?

\section{METHODOLOGICAL CONSIDERATIONS}

Approaches towards natural hazards from a cultural history perspective have become very popular in the last decade. ${ }^{9}$ These focus on the perception, interpretation, (risk) management and memory of those events by the affected people and by human societies in general. In this study, the term 'natural hazard' means the physical event, which in some instances impacts on the human environment, whereas 'natural disaster' is used to denote the perception of such an event by those involved.

1. See Schwarzl 1956; Kresser 1957; Kretschmer/Tschulk 1993; Lauscher 1996; Roth 1997; Gugerbauer/Dürr 1999; Hieble/Lämmermeyer/Schmidbauer 2003; Rohr 2003, 2004, 2005, 2006.

2. Lehner 1995; Nussbaumer 1996; Fliri 1998; Rohr 2007.

3. Wacha 1959; Zisser 1989; Auer 1993; Auer/Böhm/Schöner 2001; Strömmer 2003.

4. Schmidt 2000; Deutsch/Pörtge 2002; Glaser 2008 and many others.

5. Pfister 1999, 2002; Pfister/Wetter 2011; Wetter et al. 2011 and many others.

6. Brázdil/Kotyza 1995, 1999, 2000; Brázdil et al. 2005 and others.

7. Kiss 2009; Kiss 2011 and others.

8. Brázdil et al. 1999.

9. For the most up-to-date historiography see Rohr 2007, pp. 36-45. 
Several factors are necessary for a natural hazard to be considered a natural disaster: ${ }^{10}$

(a) the helplessness of the people trying to cope with the damage, with the available means;

(b) the inability of individuals to explain and understand the event;

(c) the material and personal suffering;

(d) the unexpectedness of the event, which depends on how prepared a society is for one-time or recurrent threats;

(e) whether there is a series of natural hazards within a short period of time, which can raise the vulnerability of the afflicted people;

(f) the symbolic connotations and patterns of interpretation, such as connections to natural disasters described in the Bible; and

(g) the general predicament, such as the simultaneous economic, religious and climatic crises during the sixteenth century in Europe.

Unexpected and sudden natural hazards, such as earthquakes, storm surges, severe thunderstorms with hail, or ice floods, are typically perceived as disasters, because people do not have time to install an effective system of prevention, which, in turn, means the number of victims will be higher. In some cases carelessness also plays a role, if settlements are erected in dangerous places or unsuitable building materials are used.

If a society is prepared to cope with an environmental risk, people will account for it in their daily life and their socio-economic system. They will adapt their settling places and their behaviour to minimise risks, based on their experience. The grade of vulnerability of such a society is lower and the result can be a 'culture of disaster' ${ }^{\prime 11}$ or, more correctly, a 'culture of risk management'. ${ }^{12}$ In many cases the affected people will no longer consider most natural hazards as disasters. In such societies, people know about the reasons and indicators for those extreme events. They undertake strategies of prevention and in times without threats dykes are built and maintained regularly, settlements are located on relatively secure ground and the building techniques of houses are adapted to the risk (e.g. no windows to the ground floor, roof constructions that can sustain heavy storms). As far as is possible, warning systems are installed as a further preventative measure. It will be shown in this study that such a 'culture of risk management' also existed among urban communities in premodern Central Europe.

10. Rohr 2007, pp. 50-57; Rohr 2009, p. 68.

11. Bankoff 2003, taking the Philippines as an example.

12. Rohr 2007. Other 'cultures of risk management' can be found along many other rivers in pre-modern Europe. See among others Schenk 2010 on Florence and Strassburg. For cultural adaptation to storm surges along the North Sea shore see Jakubowski-Tiessen 1992, 2005; Allemeyer 2005. 


\section{CHRISTIAN ROHR}

\section{A MAJOR SUMMER FLOOD AND A SUDDEN ICE FLOOD IN KREMS, LOWER AUSTRIA (1572/73)}

The city of Krems, Lower Austria, is situated on the Danube River, $80 \mathrm{~km}$ west of Vienna. Before reaching Krems, the Danube River runs through a 30 $\mathrm{km}$ narrow passage called Wachau. The whole region has been famous for its vineyards since the Middle Ages. Floods of the Danube River are very common in this area. In addition to that, the area of Krems and its twin city, Stein, are affected by ice floods, caused by a flat riverbed. ${ }^{13}$

The period around 1570 is well known for many extreme weather events. Harvests were often destroyed or very poor due to bad weather. During this first peak time of the 'Little Ice Age' prices for wheat and rye rose significantly. In addition, people suffered from extra taxes for the wars of the Hapsburg emperors against the Ottomans. In Austria, a series of major floods occurred in 1567, 1569 and $1572 .{ }^{14}$ Furthermore, the city of Krems was hit by a severe ice flood in January 1573. The accumulation of so many destructive events was responsible for them being viewed as a disaster even in a 'culture of flood management'. People could not cope with the damage with the available means any longer. As a consequence, the city council of Krems wrote a petition to the emperor and landlord Maximilian II (1564-1576), dated 17 February 1573. ${ }^{15}$ In the first part of the document, the councillors described the effects of the 1572 summer flood, which had been severe but manageable. Due to the subsequent ice flood, however, they had been out of their depth and pleaded with the emperor to give financial support.

The damage caused by the summer flood is described in great detail. The larger part of the twin cities of Krems and Stein was flooded; most of the walls had been soaked by the water. In Stein, even the archive of the orphanage, including the charters and accounts, was destroyed. In this way, the legal basis and the administrative memory also got lost. ${ }^{16}$ The city walls and many houses had been severely damaged and could not be repaired until the winter. So, vulnerability to a second event was much higher than usual.

For the winemakers of Krems, the economic loss was even greater: most of the vineyards, fields and meadows near the river were totally ruined ${ }^{17}$ It may be suggested that the report in the petition was exaggerated to cause pity, as a

13. According to documentary evidence, major ice floods occurred in the area of Krems in the years of 1439, 1573, 1595, 1622, 1682, 1740, 1768, 1784, 1789, 1809, and 1830. See Strömmer 2003: 138-140 (on 1740), 169-171 (on 1768), 210-213 (on 1784), 226-227 (on 1789), 356-357 (on 1809), and 295-301 (on 1830); Rohr 2007, p. 336.

14. See in detail Rohr 2007, pp. 243-257.

15. The petition is edited by Kinzl 1869, pp.150-153 and Rohr 2007, pp. 254-256 and 332-336. The original, formerly preserved in the Vienna Finanz- und Hofkammerarchiv, seems to be lost.

16. Petition to the emperor Maximilian II from February 17th, 1573, ed. Kinzl 1869, p. 150.

17. Ibid. ed. Kinzl 1869, p. 150. 
major part of the vineyards was situated on the slopes high above the Danube River. However the houses and at least some of the wine cellars were located near the river shore.

Due to the results of the summer flood, the ice flood of 9 January 1573 became a real disaster. In the petition to the emperor, the dramatic event is again described in great depth. The ice floes on the Danube River built up a large dam within a few hours and the water rose quickly, bringing more and more ice floes to the city. Finally, the water and the ice demolished parts of the walls, entered the city centre and flooded some streets up to the windows of

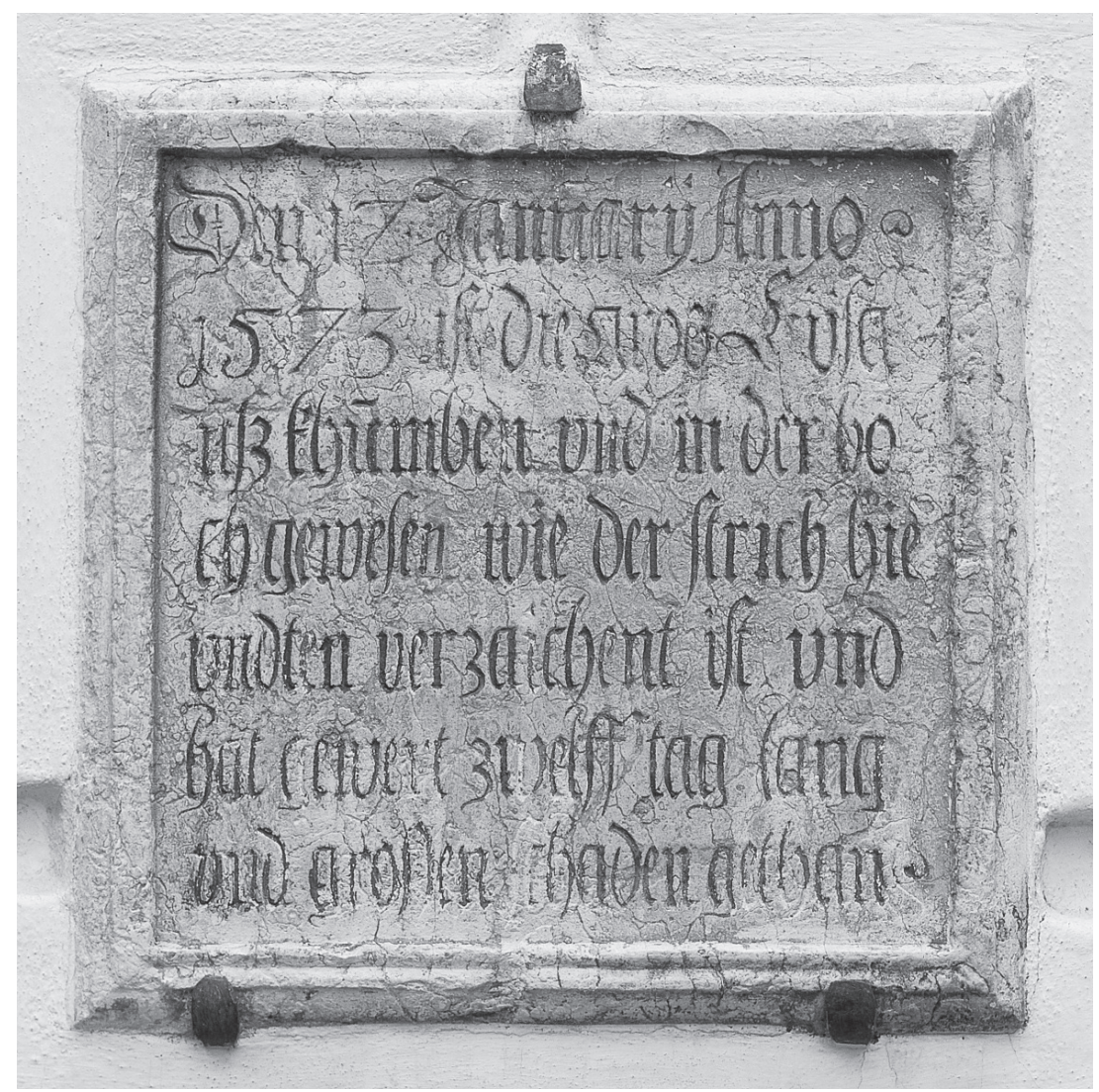

Figure 1. Inscription and flood mark related to the ice flood of 1573 in Krems. The inscription fixed to the Steinertor gate says: 'Den 12 January Anno 1573 ist die gros Eysgüß khu(m)mben vnd in der höch gewesen wie der strich hie vndten verzaichent ist vnd hat gewert zwelff tag lang und grossen [s]chaden gethan' ('On 12 January in the year of 1573 a huge ice flood happened and reached the level shown by the line below. It lasted for 12 days and caused immense damage'). 


\section{CHRISTIAN ROHR}

the houses. The peak level of the ice flood was 1.5 feet higher than the summer flood. Only a third of the twin cities remained dry. The inhabitants could not rescue their cattle, pets and hardware and they could only escape by climbing onto the roofs of their houses. ${ }^{18}$ The people could not start the clean-up operations for 12 days and, even six weeks after the event, ice-floes were lying around in the streets. ${ }^{19}$

According to the petition, the loss of wine and grain stored in the houses had been enormous. The future for the winemakers was dark: the orchards and vineyards were devastated for years, their houses severely damaged and the wine cellars no longer fit for purpose. An unbearable disaster had befallen the citizens. The petition concluded that more than 40 houses in Stein and a similar number in Krems would remain empty and deserted; the winemakers would not be able to sell their products and would therefore suffer from poverty. ${ }^{20}$

Evacuations forced by floods were probably not unusual in Krems. The municipal regulation of 1524 includes a single paragraph on this subject, entitled 'About the problems of the citizens, when floods swamp their wine cellars'. It says:

Furthermore, numerous citizens of Stein, whose houses are situated near the river shore, complained that they had to suffer remarkable losses, when floods swamp their wine cellars. ... Now, these winemakers are allowed to bring their wine casks to a secure place and to sell wine there. In this way, the winemakers should still be able to provide for their wives and children. ${ }^{21}$

Nevertheless, this regulation did not protect the winemakers in the ice flood of 1573 , because it happened so suddenly and during the night.

The real dimensions of the damage, however, might not have been as dramatic as reported in the petition to the emperor. It is assumed that 'only' the districts of the city situated in the plains near the shore of the river were hit substantially. People obviously managed to escape in time and they were presumably given shelter in the houses of other citizens, because there is no mention of any who became homeless, drowned or froze to death.

In the Vienna Finanz- und Hofkammerarchiv (Archive of the Imperial Chamber), an interesting document has been preserved. It appears that some rich citizens from Krems granted a credit of 5,500 guilders to the emperor, who had major problems with financing his war against the Ottomans in present-day

18. Ibid. ed. Kinzl 1869, pp. 150-151.

19. Ibid. ed. Kinzl 1869, p. 151.

20. Ibid. ed. Kinzl 1869, pp. 151-152. In 1565, the twin cities of Stein and Krems consisted of 400 houses each (ed. Kinzl 1869, p. 137). This means that 10 per cent of the houses remained uninhabitable.

21. Municipal regulation for Krems and Stein from March 12th, 1524, Article 63 (ed. Brunner 1953). See in more detail Rohr 2007, pp. 377-378 on this regulation. 
Hungary. ${ }^{22}$ Those inhabitants of Krems obviously came through the disasters of 1572 and 1573 without remarkable losses.

The mental management and memory of the catastrophe was achieved by fixing flood inscriptions, which recorded the date and the water level. Such tablets can be found in several public places in Krems, in particular on the town gates (Figure 1).

\section{URBAN ECONOMIC STRUCTURES IN A 'CULTURE OF FLOOD MANAGEMENT': THE EXAMPLE OF WELS (FOURTEENTH- SIXTEENTH CENTURY)}

The examples of Krems and Stein show how people dealt with two consecutive extreme events. In addition, we have to ask about the perception and management of 'ordinary floods', i.e. those that occur frequently. Normally, these events are not recorded in annals or chronicles, because they were not deemed by the affected people to be worth mentioning. Such events can only be reconstructed from economic sources, such as a series of municipal accounts and the like. There are a small number of cities in Central Europe, where such accounts have survived; the city of Wels is one of these.

Wels, a town with Roman origins, is situated on the Traun River. Close to Wels, the river is widely branched out, an ideal place for a bridge, as a copperplate print by Matthaeus Merian from 1649 shows (Figure 2). In the fifth century, floods appear to have been responsible for the decline of the town. A bridge across the Traun River had existed in Roman times, whereas the medieval bridge is first mentioned in the twelfth century.

Plenty of information on floods of the Traun River can be gained from charters: six of them dating from 1352 to 1469 are extant. They were granted by the Hapsburg dukes of Austria, who were also the sovereigns of the city of Wels. To prevent damage from floods and to accelerate repairs, several privileges were given to the citizens of Wels ${ }^{23}$ :

22. Vienna, Finanz- und Hofkammerarchiv, Niederösterreichische Herrschaftsakten, K 57/a. In this series of documents, dating from 1572 and 1573, the summer flood of 1572 and the ice flood of 1573 are not mentioned at all. The loan of 5,500 guilders was the last part of a 15,000 guilders credit, granted by the nobleman Michael Freiherr von Eyzing from Krems. During the following years, the emperor asked for several further credits higher than 10,000 guilders. In the mid-sixteenth century the average income of a worker in the vineyards was 3 shillings per day or 1 guilder for ten days; the school master earned 100 guilders per year. In 1569, a mill in Krems was sold for 700 guilders. See ed. Kinzl 1869, pp. 124, 128, and 144.

23. Duke Albrecht II of Austria for the city of Wels, June 5th, 1352 (original charter preserved in the Municipal Archive of Wels, Charter Series); Duke Albrecht II of Austria for the city of Wels, June 5th, 1352 (not identical with the first one, copy inserted in the 'Pancharte' town book of 1582 preserved in the Municipal Archive of Wels); Duke Albrecht III of Austria to the abbots of the nearby Benedictine monasteries of Kremsmünster and Lambach, November 1st, 1376; Dukes Leopold IV and Ernst for the city of Wels, September 30th, 1409; King 


\section{CHRISTIAN ROHR}

(a) the taxes at the toll house in Wels on salt, wine and textiles were dedicated to the construction of water defences (1352a);

(b) the tax obligations of the citizens of Wels were reduced by the Hapsburg dukes. More money should be spent on dykes and other water defences (1409);

(c) land owners had to permit the construction of water defences on their properties (1352b); and

(d) the land owners, their bondsmen and two large monasteries in the neighbourhood had to assist if large amounts of debris had to be removed after a flood $(1376,1445$, and 1469).

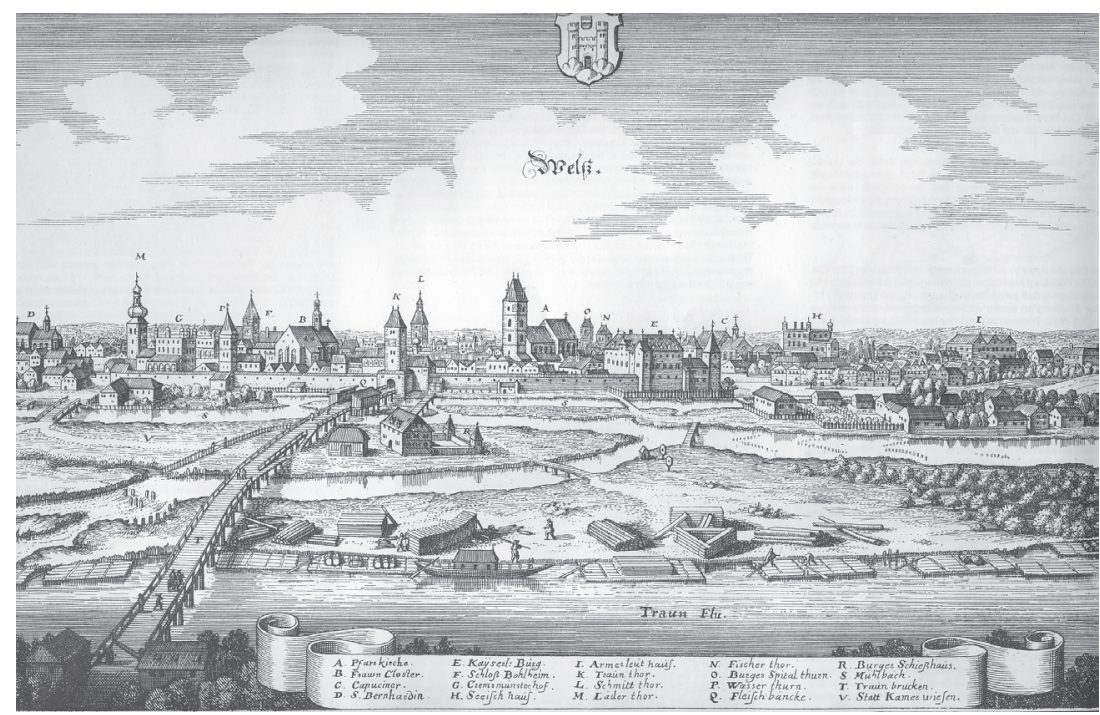

Figure 2. Wels, Upper Austria, copperplate print by Matthaeus Merian (1649). The 600-metre-long bridge obviously did not change its appearance significantly between the fourteenth and the nineteenth centuries. Rafts and large stockpiles of timber are shown in the centre. The stores of the butchers (fleischpenckh) are located on the bridge near the town gate. Right from the bridge, situated on a gravel bank, stands the barn (bruckstadel). Along the riverside, protective wooden structures (schlachten) are intended to fortify the gravel banks. Inside the river (left from the bridge and on the right near the city) other protective wooden structures (wuer) are erected to catch the driftwood. In 1899, the last wooden bridge was destroyed by a flood and was replaced by a stone-and-iron construction.

Friedrich IV for the city of Wels, June 26th, 1445; Emperor Friedrich III for the city of Wels, March 29th, 1469 (all preserved as a copy inserted in the 'Pancharte'). For a new, revised edition and commentary see Rohr 2007, pp. 283-287. 
Normative sources such as charters granted by the Dukes of Austria tell us about the society's management of floods, but nothing about individual reactions and the collective memory of the events. The charters can be seen as an answer to disastrous floods, which could not be dealt with by the available means; regional solidarity was a necessity. But the exact number of floods cannot be calculated on the basis of normative sources.

From its establishment in the thirteenth century onwards, the office of bridge master was responsible for any repairs to the bridge and the protective structures associated with it. According to a series of charters, the bridge master received his annual budget from the revenue of a nearby church. ${ }^{24}$ The oldest accounts of the bridge master date from 1350, but a near-continuous series of accounts has survived starting as late as $1441 . .^{25}$ The incoming and outgoing accounts contain detailed information about the timber purchased for the bridge and about the expenses paid to craftsmen to repair the bridge after damage caused by floods and other events. Unlike the overall town accounts, the expenses mentioned in the accounts of the bridge master only concern the bridge, not other buildings. The entries were made weekly.

The municipal accounts of the bridge master of Wels have hardly ever been utilised as a basis for detailed studies of floods and flood management. The accounts for the years from 1441 to the end of the sixteenth century cover more than 10,000 hand written pages; the late Gothic cursive script of the accounts is often extremely difficult to read, even for specialised historians (Figure 3).

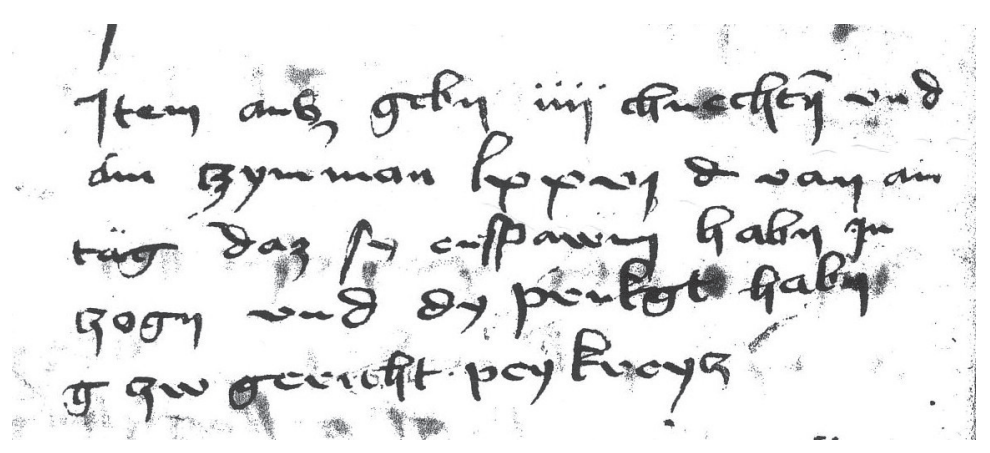

Figure 3. The accounts of the bridge master of Wels, entry from 1443 (Wels, Municipal Archive, Bruckamtsrechnungen 1443, fol. 8v): 'Item aus gebn iiii chnecht(e)n und dm zymman lxxvi d van ain täg daz sy enspawm haben inzogn und dy prukgt haben $g \mathrm{zw}$ gericht pey kreyz' ('And [after the flood] I have given to four servants and to the carpenter 76 pence for one day, because they had installed long timber and had repaired the [part of the] bridge near the Holy Cross').

24. See in detail Holter 1955.

25. Wels, Municipal Archive, Accounts of the Bridge Masters (Bruckamtsrechnungen, BAR). 


\section{CHRISTIAN ROHR}

From the information on repairs to the bridge, we are able to ascertain the date when the flood occurred, and the beginning and the end of the work to repair or to maintain the bridge. In this way, a parameter for the intensity of floods can be deduced:

(1) little or moderate floods without major destruction

(2) larger floods, destruction can be overcome within one month

(3) extraordinary floods, severe destruction (e.g. bridges totally destroyed), can be overcome within three months

(4) extreme floods, economic and social infrastructure destroyed, perception as disaster, flood marks ${ }^{26}$.

The examination of the accounts of the bridge master shows that 'ordinary floods' seem to have happened nearly every year; sometimes they occurred twice or three times a year. Looking at the years around 1500 it can be seen that only one of the 14 years passed without a flood (Table 1). Some of the major events, such as in 1499, are not mentioned in any narrative source.

Table 1. Floods of the Traun River, 1497-1510, according to the accounts of the bridge masters of Wels.

\begin{tabular}{|l|l|l|l|}
\hline Year & Month & Flood & Intensity \\
\hline 1497 & May/early June & flood with destruction & strong (2) \\
\hline 1498 & March, August? & two floods & moderate (1/1) \\
\hline $\mathbf{1 4 9 9}$ & end of May/June & flood with severe destruction & very strong (3) \\
\hline 1500 & April, May & two? floods with destruction & moderate/strong (2) \\
\hline $\mathbf{1 5 0 1}$ & July?, August & disastrous flood & extremely strong (4) \\
\hline 1502 & & no flood & \\
\hline $\mathbf{1 5 0 3}$ & September & flood with severe destruction & very strong (3) \\
\hline 1504 & May & flood & moderate (1) \\
\hline 1505 & May/June, August & two floods & moderate (1/1) \\
\hline 1506 & July & flood? & little (1) \\
\hline 1507 & August? & flood? & moderate (1) \\
\hline $\mathbf{1 5 0 8}$ & July, August & two floods with destruction & very strong (3) \\
\hline 1509 & Autumn? & flood? & little (1) \\
\hline 1510 & & no accounts & \\
\hline
\end{tabular}

26. Rohr 2007, p. 206. A three category scale was introduced by Pfister/Hächler 1991, and elaborated in more detail by Deutsch/Pörtge 2002. The scale is mainly based on the water level, measured by flood marks. In many cases, however, flood marks do not exist any longer or have been affixed only for the largest floods. They are totally missing, where the city is situated in an elevated place so that the city itself is not hit by the flood. Repairs of bridges are, therefore, better indicators to reconstruct the intensity of floods. The categories 1 and 2 are the same in both systems, 


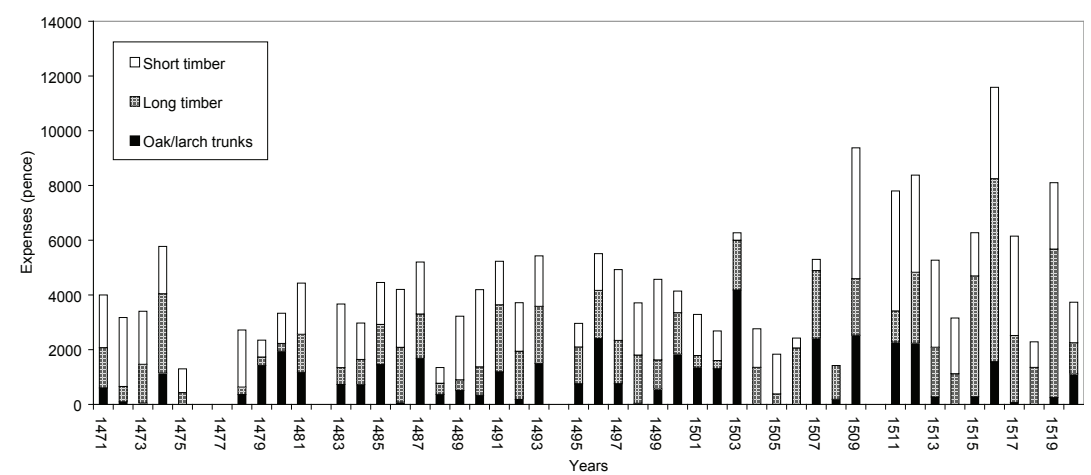

Figure 4. Expenses of the bridge master of Wels for timber (1471-1520). The accounts for the years 1476, 1477, 1494 and 1510 are missing. For the exact amount of purchased short timber, long timber and oak/larch trunks see Rohr 2007: 558-559

(appendix: table 3).

Floods in the catchment area of the Danube River in present-day Austria mostly took place in summer, when continuous rain came from lows in Northern Italy (the so-called 'Vb weather') ${ }^{27}$ In addition to that, floods also appeared in spring after snowmelt, but rarely in autumn or winter. ${ }^{28}$ Floods and their management must have been a usual part of daily life. We also have some clues that a primitive warning system existed on the Traun River: salt shippers from the upper Traun River valley, the so-called Salzkammergut, advised the bridge master to remove the bridge surface when a major flood was expected. ${ }^{29}$

Large amounts of timber were bought every year, regardless of whether there had been a flood or not. Obviously the bridge masters established large depots, as they can be seen on Figure 2. There are three types of timber mentioned in the accounts: oak or larch trunks used for the piles, long timber (enspawm) for the connections between the piles and short timber (sträupawm) for the coverage of the bridge and other water defences. Figure 4 demonstrates that the overall expenses for timber were quite constant from the 1470 s to 1500. The prices for long and short timber per unit remained at the same level

27. During a Vb weather situation, low pressure cyclones grow up over the northern Mediterranean and then move in a north-west direction. The result is heavy rain in the Eastern Alps and subsequently in present-day Czech Republic, Slovakia, Hungary and Southern Poland. The last major flood of this type occurred in August 2002, with extraordinary damage in the catchment area of the Danube River in Austria, but also along the Vltava and Elbe (Labe) Rivers. The cities of Prague and Dresden were severely flooded. See Mudelsee et al. 2004.

28. See Rohr 2006: 839; Rohr 2007, pp. 209-213.

29. Such a system is shown to have been in place for the years of 1560,1567 and 1572 (Wels, Municipal Archive, BAR 1560, fol. 33r; BAR 1567, fol. 28v; BAR 1572, fol. 31v-32r). See also Rohr 2007: 371. 


\section{CHRISTIAN ROHR}

for this period. The varying expenses only reflect the varying number of timbers bought year by year. As there is no direct connection to specific flood events, we may assume that the purchased amount of short and long timber depended on supply and demand.

The price for oak trunks varied, according to the diameter and quality. After the 'millennium flood' of 1501, large numbers of oak trunks were bought (40-50 per year). Following the subsequent flood of 1503, no oak trunks were available on the market and for a couple of years they were substituted by larch trunks. After the fourth major flood within one decade in 1508 the overall expenses reached a new peak and remained very high for some years. From this time onwards, the prices for short and long timber per item rose significantly. This can be put down to the fact that the demand for timber in the whole area had increased rather than to general price inflation.

However, there were also some who benefited from the floods. Carpenters and other craftsmen earned a lot of money from the repairs. In many of the years, the works for the bridge must have provided 10-20 per cent of the annual turnover of carpenters, considering the number of weeks they spent repairing the bridge. Also, fishermen could increase their income when the river could not be crossed via the bridge. They established a ferry service and provided the transport of timber for the carpenters. ${ }^{30}$

During the nineteenth century, larger straightenings of the Traun River were made in the area of Wels. The new riverbed was now much deeper than in the centuries before. As a result, an 'ordinary' higher water level did not cause flooding any longer, and the citizens of Wels allowed themselves to feel secure. The meadows situated between the new riverbed and the old city walls gave way to some impressive bourgeois villas, built in the 1880s. However, the embankments were not high enough to prevent the disastrous floods of July/ August 1897 and September 1899. The local knowledge of a 'culture of flood management' had vanished. ${ }^{31}$

\section{CONCLUSIONS}

Both examples have shown the existence of a 'culture of flood management' in pre-modern urban areas. Municipal regulations and charters contain articles on flood management. The most affected people were allowed to relax certain rules, such as the winemakers of Krems who were allowed to sell their wine outside their properties. Solidarity within the city prevented a higher number of victims but, as the charters from Wels have shown, such unity was not

30. After the 'millennium flood' of 1501, at least 14 fishermen and their servants brought people from one side of the river to the other and supplied the carpenters with timber: Wels, Municipal Archive, BAR 1501, fol. 14r-16v.

31. See in detail Rohr 2012. 
always a natural course of action. In general, economic and social life at the time was adapted to frequent flooding. Due to the preparedness of the population, most of the floods were not perceived as disasters. A lack of prevention and risk management can be seen only in the context of series of major floods and sudden events, such as ice floods. The example of Krems also shows that the richer population was more prepared for the risk: since the Middle Ages the noblemen and the patricians of Krems had lived in secure quarters and had no financial losses even in 1572 and 1573 . The natural hazards mainly hit the poorer population living along the riverside.

\section{BIBLIOGRAPHY}

\section{Primary Sources}

Brunner, Otto (ed.) 1953. Die Rechtsquellen der Städte Krems und Stein (Fontes Rerum Austriacarum III, 1). Graz / Cologne: Böhlau.

Merian, Matthaeus. 1649. Topographia Provinciarum Austriacarum. Austriae, Styriae, Carniolae, Tyrolis, etc. Das ist Beschreibung und Abbildung der fürnembsten Stätt und Plätz in den Österreichischen Landen etc. Frankfurt am Main: Matthaeus Merian. [facsimile reprint Kassel / Basel: Bärenreiter 1963].

Wels, Municipal Archive, Bruckamtsrechnungen (Accounts of the bridge master), 1441-1599.

\section{Secondary Sources}

Allemeyer, Marie Luisa. 2005. 'Kein Land ohne Deich ...!'Lebenswelten einer Küstengesellschaft in der Frühen Neuzeit (Veröffentlichungen des Max-PlanckInstituts für Geschichte 222). Göttingen: Vandenhoeck \& Ruprecht.

Auer, Ingeborg. 1993. Niederschlagsschwankungen in Österreich seit Beginn der instrumentellen Beobachtungen durch die Zentralanstalt für Meteorologie und Geodynamik (Österreichische Beiträge zu Meteorologie und Geophysik 7). Vienna: Zentralanstalt für Meteorologie und Geodynamik.

Auer, Ingeborg, Reinhard Böhm, and Wolfgang Schöner. 2001. Austrian Long-Term Climate 1767-2000. Multiple Instrumental Climate Time Series from Central Europe (Österreichische Beiträge zu Meteorologie und Geophysik 25). Vienna: Zentralanstalt für Meteorologie und Geodynamik.

Bankoff, Greg. 2003. Cultures of Disaster. Society and Natural Hazard in the Philippines. London \& New York: RoutledgeCurzon.

Brázdil, Rudolf, Petr Dobrovolný, Libor Elleder, Vilibald Kakos, Oldřich Kotyza, Vit Květoň, Jarmila Macková, Miloslav Müller, Josef Štekl, Radim Tolasz and Hubert Valášek. 2005. History of Weather and Climate in the Czech Lands, Vol. 7: Historical and Recent Floods in the Czech Republic. Brno / Prague: Masaryk University and Czech Hydrometeorological Institute. 


\section{CHRISTIAN ROHR}

Brázdil, Rudolf, Rüdiger Glaser, Christian Pfister, Petr Dobrovolný, Jean-Marc Antoine, Mariano Barriendos, Dario Camuffo, Mathias Deutsch, Silvia Enzi, Emanuela Guidoboni, Oldřich Kotyza and Fernando S. Rodrigo. 1999. 'Flood events of selected European rivers in the sixteenth century'. Climatic Change 43/1: 239-285.

Brázdil, Rudolf and Oldřich Kotyza. 1995. History of Weather and Climate in the Czech Lands, Vol. 1: Period 1000-1500 (Zürcher Geographische Schriften 62). Zurich: Geographisches Institut ETH.

Brázdil, Rudolf and Oldřich Kotyza. 1999. History of Weather and Climate in the Czech Lands, Vol. 3: Daily Weather Records in the Czech Lands in the Sixteenth Century II. Brno: Masaryk University.

Brázdil, Rudolf and Oldřich Kotyza. 2000. History of Weather and Climate in the Czech Lands, Vol. 4: Utilisation of Economic Sources for the Study of Climate Fluctuation in the Louny Region in the Fifteenth-Seventeenth Centuries. Brno: Masaryk University.

Deutsch, Mathias and Karl-Heinz Pörtge. 2002. Hochwasserereignisse in Thüringen (Thüringer Landesanstalt für Umwelt und Geologie, Schriftenreihe 63). Jena: Thüringer Landesanstalt für Umwelt und Geologie.

Fliri, Franz. 1998. Naturchronik von Tirol. Tirol-Oberpinzgau - Vorarlberg - Trentino. Beiträge zur Klimatographie von Tirol. Innsbruck: Verlag Wagner.

Glaser, Rüdiger. 2008. Klimageschichte Mitteleuropas. 1200 Jahre Wetter, Klima, Katastrophen. Darmstadt: Wissenschaftliche Buchgesellschaft.

Gugerbauer, Anna and Ernst Dürr. 1999. Vom Zorn des Inn. Hochwasserkatastrophen in Schärding und den bayerischen Nachbargemeinden. Wernstein: Verlag Wiesner.

Hieble, Horst, Herbert Lämmermeyer and Heinz Schmidbauer. 2003. Die Salzachbrücke zwischen Laufen und Oberndorf. Von der ersten Erwähnung eines Salzachüberganges im Jahre 1278 bis zur Gegenwart. Laufen: Edition Zeitdokumente Horst Hieble.

Holter, Kurt. 1955. 'Die römische Traunbrücke und die Anfänge des Welser Bruckamtes'. Jahrbuch des Musealvereines Wels 2: 124-151.

Jakubowski-Tiessen, Manfred. 1992. Sturmflut 1717. Die Bewältigung einer Naturkatastrophe in der Frühen Neuzeit (Ancien Régime. Aufklärung und Revolution 24). Munich: Oldenbourg.

Jakubowski-Tiessen, Manfred. 2005. 'Woher nehmen wir geldt zu den Küsten her ...? Eine frühneuzeitliche Flutkatastrophe und ihre finanziellen Folgen', in Naturkatastrophen und Naturrisiken in der vorindustriellen Zeit und ihre Auswirkungen auf Siedlungen und Kulturlandschaft, eds. Winfried Schenk and Andreas Dix (Siedlungsforschung. Archäologie - Geschichte - Geographie 23). Bonn: ARKUM. pp. 91-99.

Kinzl, Josef. 1869. Chronik der Städte Krems, Stein und deren nächster Umgebung. Mit den Freiheitsbriefen beider Städte und den Schriftstücken ihrer gewerblichen Innungen vom Jahre 985-1869. Krems: Verlag Pammer.

Kiss, Andrea. 2009. 'Historical climatology in Hungary: Role of documentary evidence in the study of past climates and hydrometeorological extremes'. Idöjárás. Quarterly Journal of the Hungarian Meteorological Service 113/4: 315-339.

Kiss, Andrea. 2011. Floods and Long-Term Water-Level Changes in Medieval Hungary. PhD Thesis. Budapest: Central European University. 


\section{FLOODS OF THE UPPER DANUBE}

Kresser, Werner. 1957. Die Hochwässer der Donau (Schriftenreihe des österreichischen Wasserwirtschaftsverbandes 32-33). Vienna: Springer Verlag.

Kretschmer, Helmut and Herbert Tschulk. 1993. Brände und Naturkatastrophen in Wien (Wiener Geschichtsblätter, Beiheft 1). Vienna: Verein für Geschichte der Stadt Wien.

Lauscher, Friedrich. 1996. 'Unwetterchronik des Pinzgaus, Land Salzburg, seit 1501'. Wetter und Leben. Zeitschrift für angewandte Meteorologie 38: 26-36.

Lehner, Martina. 1995. 'Und das Unglück ist von Gott gemacht ...'. Geschichte der Naturkatastrophen in Österreich. Vienna: Edition Präsens.

Mudelsee, Manfred, Michael Börngen, Gerd Tetzlaff and Uwe Grünewald. 2004. 'Extreme floods in central Europe over the past 500 years: Role of cyclone pathway Zugstrasse Vb'. Journal of Geophysical Research 109, Nr. D23101, doi:10.1029/2004JD005034.

Nussbaumer, Josef. 1996. Die Gewalt der Natur. Eine Chronik der Naturkatastrophen von 1500 bis heute. Grünbach: Edition Sandkorn.

Pfister, Christian. 1999. Wetternachhersage. 500 Jahre Klimavariationen und Naturkatastrophen (1496-1995). Berne / Stuttgart / Vienna: Verlag Paul Haupt.

Pfister, Christian (ed.) 2002. Am Tag danach. Zur Bewältigung von Naturkatastrophen in der Schweiz 1500-2000. Berne / Stuttgart / Vienna: Verlag Paul Haupt.

Pfister, Christian and Stefan Hächler. 1991. 'Überschwemmungskatastrophen im Schweizer Alpenraum seit dem Spätmittelalter. Raumzeitliche Rekonstruktion von Schadensmustern auf der Basis historischer Quellen', in Historical Climatology in Different Climatic Zones, eds. Rüdiger Glaser and Rory P. D. Walsh (Würzburger Geographische Arbeiten 80). Würzburg: Institut für Geographie / Geographische Gesellschaft. pp. 127-148.

Pfister, Christian and Oliver Wetter. 2011. 'Das Jahrtausendhochwasser von 1480 an Aare und Rhein'. Berner Zeitschrift für Geschichte 73/4: 41-50.

Rohr, Christian. 2003. 'Der Fluss als Ernährer und Zerstörer. Zur Wahrnehmung, Deutung und Bewältigung von Überschwemmungen an den Flüssen Salzach und Inn (13.-16. Jahrhundert)', in Naturkatastrophen / Catastrophes naturelles, eds. Monika Gisler, Katja Hürlimann and Agnes Nienhaus (Special Issue of Traverse. Zeitschrift für Geschichte / Revue d'Histoire 10/3). Zurich: Chronos Verlag: 37-49.

Rohr, Christian. 2004. 'Überschwemmungen an der Traun zwischen Alltag und Katastrophe. Die Welser Traunbrücke im Spiegel der Bruckamtsrechnungen des 15. und 16. Jahrhunderts'. Jahrbuch des Musealvereines Wels 33: 281-328.

Rohr, Christian. 2005. 'The Danube floods and their human response (14th to 17th c.)'. History of Meteorology 2: 71-86.

Rohr, Christian. 2006. 'Measuring the frequency and intensity of floods of the Traun River (Upper Austria), 1441-1574'. Hydrological Sciences Journal 51/5: 834-47.

Rohr, Christian. 2007. Extreme Naturereignisse im Ostalpenraum. Naturerfahrung im Spätmittelalter und am Beginn der Neuzeit (Umwelthistorische Forschungen 4). Cologne / Weimar / Vienna: Böhlau.

Rohr, Christian. 2009. 'Confronting avalanches in the Alps in the late Middle Ages and early Modern Era', in Weather, Local Knowledge and Everyday Life: Issues in 


\section{CHRISTIAN ROHR}

Integrated Climate Studies, eds. Vladimir Jankovic and Christina Barboza. Rio de Janeiro: Museu de Astronomia. pp. 67-74.

Rohr, Christian. 2012. 'Stadterweiterung Stadterweiterung versus Naturgefahr. Die Stadt Wels während der Hochwasserkatastrophen von 1897 und 1899', in Festschrift für Walter Aspernig zum 70. Geburtstag (Jahrbuch des Oberösterreichischen Musealvereines - Gesellschaft für Landeskunde 157 = Jahrbuch des Musealvereines Wels 36). Linz: Oberösterreichischer Musealverein / Wels: Musealverein Wels. pp. 551-574.

Roth, Hans. 1997. 'Die alte Laufener Salzachbrücke. Das Hochwasser als ständige Gefahr für Brücke und Stadt'. Das Salzfass. Heimatkundliche Zeitschrift des Historischen Vereins Rupertiwinkel 31/1: 5-32.

Schenk, Gerrit Jasper. 2010. 'Human Security in the Renaissance? Securitas, Infrastructure, Collective Goods and Natural Hazards in Tuscany and the Upper Rhine Valley', in The Production of Human Security in Premodern and Contemporary History / Die Produktion von Human Security in Vormoderne und Zeitgeschichte, eds. Cornel Zwierlein, Rüdiger Graf and Magnus Ressel (Special Issue of Historical Social Research / Historische Sozialforschung 34/4). Cologne: Quantum Information: 209-233.

Schmidt, Martin. 2000. Hochwasser und Hochwasserschutz in Deutschland vor 1850. Eine Auswertung alter Quellen und Karten. Munich: Oldenbourg Industrieverlag.

Schwarzl, Siegfried. 1956. Die Hochwasserbedrohung Wiens. Elementarereignisse an der Donau im Rahmen der Klimaentwicklung (Wetter und Leben, Sonderheft 4). Vienna: Österreichische Gesellschaft für Meteorologie.

Strömmer, Elisabeth. 2003. Klima-Geschichte. Methoden der Rekonstruktion und historische Perspektive. Ostösterreich 1700 bis 1830 (Forschungen und Beiträge zur Wiener Stadtgeschichte 39). Vienna: Verlag Deuticke.

Wacha, Georg. 1959. Zur Wetterchronik des Linzer Raumes, in Witterung und Klima von Linz, eds. Friedrich Lauscher and Georg Wacha (Wetter und Leben, Sonderheft 6). Vienna: Österreichische Gesellschaft für Meteorologie. pp. 3-86.

Wetter, Oliver, Christian Pfister, Rolf Weingartner, Jürg Luterbacher, Tom Reist and Jürg Trösch. 2011. 'The largest floods in the High Rhine basin since 1268 assessed from documentary and instrumental evidence'. Hydrological Sciences Journal 56/5: 733-758.

Zisser, Helmut. 1989. Die Hochwässer der Donau. M.A. Thesis, Vienna: Technical University of Vienna. 